Accepted by Journal of Ethnic and Migration Studies, 5 November 2019 https://doi.org/10.1080/1369183X.2019.1691513

Migration impact inside-out: stayers, sociology and social remittances

\author{
Anne White \\ ${ }^{a}$ School of Slavonic and East European Studies, University College London, United \\ Kingdom
}

Anne.White@ucl.ac.uk UCL SSEES, 16 Taviton St, London WC1H 0BW 


\section{Migration impact inside-out: stayers, sociology and social remittances}

The article presents a novel approach to understanding the impact of migration on sending countries. It looks at the topic the other way round from conventional approaches. Rather than only studying migrants' influence on countries of origin, as migration scholars naturally do, I recommend first mapping social trends in sending countries to understand the most significant changes, before analysing why change takes place. Such analysis involves qualitative sociological research to understand the causes of change: how social remittances and more indirect migration influences combine with other factors. Focusing on sending country residents, the approach also applies concepts and findings from receiving societies research. The approach encourages a thorough investigation of transnational social space, seeing sociological phenomena such as socialisation or social activism taking place across international borders. The case study is twenty-first century Europe, with its dense and diverse migration patterns. The article discusses my experience of applying the approach to Poland, suggesting that migration exposure's special role may be to reinforce national trends (e.g. towards more open-to-difference attitudes) even in social groups and geographical locations which are generally more conservative. Finally, I discuss how the approach might be applied in other post-communist countries, as well as further afield.

Keywords: sending countries, social remittances, stayers, Poland, EU, CEE

\section{Introduction}

This article offers some ideas for understanding how migration contributes to social change in sending countries. It aims to justify a novel, 'inside-out' approach, which can be used to study the society of any country, whatever its level of development and whether or not it is usually considered to have a 'sending' identity. The approach could be applied equally to the United Kingdom or Germany as to Moldova or Morocco, although the specific Polish case study is most applicable to other EU member states. 'Migration' is understood broadly to encompass all forms of mobility, including visits 
by stayers to friends and relatives abroad. Although scholars from other disciplines, notably economists and demographers, adopt a type of inside-out approach, mainstream sociologists and migration scholars collaborate less often, as noted for example by Castles (2010) and Dahinden (2016).

Briefly, the idea is first to map social change in the sending country, identifying important trends. For example, is society (disaggregated down to its constituent social groups) becoming more tolerant, or less, according to various indicators? The next step is to consider why changes may be happening. Finally, the researcher can investigate the role, if any, of migration in contributing to change. Faist (2016: 331) observes that 'it is difficult to clearly pinpoint the impact of cross-border mobility, given the overall matrix of change and transformation produced by globalization'. As discussed below, a few scholars (notably Levitt, Lamba-Nieves and de Haas) have argued that migration may reinforce other globalising trends, while Portes (2010) emphasises its capacity to reinforce the status quo. The inside-out approach uses qualitative research to understand how and why such reinforcement happens.

An inside-out approach, despite its micro-level focus in the final stage, tries to illuminate migration influences in areas of social change which the researcher has identified as significant nationally and about which they can present some precise evidence. By contrast, migration scholars are not usually mainstream sociologists of the countries they research, and, although they may refer to social trends, they frequently do not find it necessary to present these in detail in their publications. An inside-out approach also avoids over-emphasising migration as a source of change, which might happen if one concentrated only on interviewing migrants. It does not privilege migrants 
over stayers (defined to include return migrants): ${ }^{1}$ this is largely an 'immobility perspective' (Stockdale and Haartsen 2018). After all, if one is interested in social change in a given country, stayers must be the main focus.

Applying the approach implies either close collaboration between sociologists and migration researchers, or that researchers should possess expertise in both areas. Both 'migration' and 'society' are complex phenomena, so understanding the impact of 'migration' on 'society' entails knowing details of both, asking which parts of society are changing, how, why, and because of what types of migration. The approach does not imply measuring migration impact: the causation is too complex to make this feasible. For example, claiming that 30 per cent of change occurred thanks to migration would be absurd. However, the mechanics of change do become clearer if the approach is applied. Although the inside-out approach can be applied to selected areas of social change, such as gender roles (White 2016: 70-73), this article adopts a wider perspective. I draw on White, Grabowska, Kaczmarczyk and Slany, The Impact of Migration on Poland: EU Mobility and Social Change (UCL Press, 2018), in which we implement the approach. This article takes several steps further the discussion in my concluding chapter to our book, which expresses the hope that our methodology could be replicated in other countries, without discussing how to do so.

The article is structured as follows. The next section explores relevant concepts, particularly reviewing literature about migration impact and social remittances, but also problematising the concept of the 'sending country'. I then explain the methodology in more detail, and discuss my experience of applying it to Poland. The final part of the

${ }^{1}$ Within the resident population there is a spectrum of different exposure to life abroad and, especially if one adopts a broad definition of 'migration', it is hard to draw a line between those with 'no' migration experience and those with 'some'. 
article pulls out ways in which the Polish experience could be used to understand other sending countries, particularly those in Central and Eastern Europe (CEE), and the special role of the EU as a 'mobility laboratory'.

\section{Literature and Concepts}

This article builds on ideas from the 2010 JEMS special issue on migration and social change. Portes (2010) in particular provides a helpful framework of analysis, distinguishing different areas of change (broadly divided between culture and social structure); different layers (from deep to superficial); and different time periods (suggesting that change often germinates over two or three generations). Portes applies his framework to both sending and receiving societies; one of his most important claims is that one can use the same approaches to understanding the impact of migration on both. Another significant feature of the article is that Portes discusses social change from a general sociological perspective. Castles (2010: 1566) advocates the identical approach: 'A key problem [in migration research] is the tendency to see migration as quite distinct from broader social relationships and change processes. I will argue for the need to embed migration research in a more general understanding of contemporary society.' Taking the example of worsening employment conditions in receiving countries, Castles discusses how this partly links to migration.

My article similarly argues that we should mainstream migration research by connecting it to general sociology. However, whereas Portes and Castles in their specific examples (like Dahinden 2016 in her follow-up article) focus more on receiving societies, the case study in this article is of a society typically considered to fall into the 'sending' category.

Unlike Portes and Castles, most other writers discuss separately the impacts of 'emigration' on sending and 'immigration' on receiving societies. This reflects 
assumptions that the world divides between two country types, with 'sending' and 'receiving' status presumably defined by net emigration and immigration statistics. Sending locations are usually equated with developing countries, so the main point of discussion in such literature is often how and/or whether migration is good or bad for development. (For reviews of this literature, see e.g. De Haas 2012; Glick Schiller 2012.) However, despite the richness of the literature, and its in recent years helpful focus on the main effect of migration as being the creation of ties between sending and receiving societies, it is often not applicable to countries which are not 'developing'. Moreover, whereas migrants from other continents often display a collective commitment to their communities of origin (Lacroix 2014; Levitt and Lamba-Nieves 2011), migration from sending countries in Europe often seems to be an individual or family project, as discussed in more detail below.

In places with self-images as sending countries, such as Lithuania, Ukraine or Moldova, the impact of migration is not something which can be ignored, and gaps created by migration, such as population loss, brain drain, and absent parents, concern policy-makers and the public. A recent volume is tellingly entitled Coping with Emigration in Baltic and East European Countries (OECD 2013). Alongside, and sometimes influencing researchers' attempts to uncover good and bad impacts, is a tendency among sending country politicians, journalists and religious figures to moralise about migration and stigmatise migrants: for example, to complain about selfish materialism among parents who 'leave behind' their children (Mădroane 2016 (Romania), Markova 2010 (Bulgaria), White 2017 (Poland)). Receiving societies can be considered corrupting influences. For example, the head of a teetotallers' association in a conservative region of Poland complained in 2007: 'The liberal attitudes towards drinking, moral laxity and dissipation which prevail in Belgium have a very negative 
effect on migrants who go there. Not everyone is sufficiently strong-willed and motivated to resist' (Wasek 2007).

A less normative approach seems desirable, not least because researchers who conduct qualitative research with migrants often gain quite other perspectives. Migrant parents, for example, explain their behaviour as self-sacrifice which creates sufficiently positive outcomes for the family to outweigh emotional costs (Piperno 2012, White 2017). Categorising impacts as good or bad makes for easy frames of analysis, useful for example when teaching migration impacts at school, ${ }^{2}$ but this is insufficient justification for normativity.

Additionally, the very fact of labelling countries 'sending' risks reproducing stereotyped hierarchies. Migration happens because Place B is less attractive than Place A, hence 'sending country' status is implicitly inferior, and the sending country, it may be assumed, can only learn from the receiving one. Since stereotypes cloud thought, they are likely to stop researchers noticing some significant migration phenomena, such as when influences happen in the opposite direction, and sending countries export ideas as well as people to receiving ones. Moreover, there are surely many aspects of life, such as changes in eating habits or tastes in clothing and children's names, or the emergence of a new genre of migrant fiction (for instance post-accession Polish migration novels), which are hard to classify as either good or bad.

By way of illustrating the futility of overly normative approaches, one might consider how contemporary migration of UK nationals from the UK changes British

${ }^{2}$ See for example the impacts of migration sections on the BBC Bitesize GCSE geography site http://www.bbc.co.uk/schools/gcsebitesize/geography/migration/types_migration_re v3.shtml or the Polish educational site e-szkola: https://eszkola.pl/wos/emigracjazarobkowa-polakow-skutki-8188.html (last accessed 31 December 2018). 
society. A diverse range of Britons migrate to other EU countries (Benton 2017) and further afield. Though numbers are quite large, with an estimated 128,000 British people emigrating in the year ending June 2018 (ONS 2018: 5), the question of how this affects British society is rarely posed or answered. There is some concern about the impact of a 'brain drain' of British-trained doctors (BMA 2015). However, an ordinary British person, asked to state how migration from the UK affects their own life, would probably not mention textbook migration impacts such as brain drain and would be more likely to discuss their contacts with family and friends, and practices such as communicating with people abroad, or going to visit them, which can hardly be classified as good or bad. Most British citizens have friends and family outside the UK. (Cable (2014) asserts 57 per cent, though he claims most do not keep in contact.) ${ }^{3}$ The chief impact of migration from the UK seems to be the creation of millions of individual transnational social fields.

Portes' (2010) article helps one undertand what, if any, society-wide impacts might ensue from this plethora of individual contacts. Some phenomena would belong to the type he labels superficial, such as changing tastes in food, but the migration of UK nationals could also have collective impact on values. For example, an interesting (but as far as I know unanswered) question is whether and how having lived or visited migrants abroad makes British people more accepting of immigration to the UK. Mau et al (2008) partly answer this question with regard to Germany. The authors, having established that in 200647 per cent of German citizens 'regularly communicate privately with at least one person living in a foreign country' (Mau et al 2008: 3) used survey evidence to show a correlation between transnational communications and greater tolerance and respect for foreigners, although having stayed or lived abroad did

\footnotetext{
${ }^{3}$ Based on a survey by the telephone company Ringo.co (details unavailable).
} 
not seem to be significant (Mau et al 2008: 15). Mau et al's research makes one appreciate the merits of downplaying the sending and receiving distinction and just considering the effects of transnational social relations on social trends in any country.

If migration's main influence is to tie individuals in different countries together in transnational social space, the 'social continuum' (Guarnizo et al. 1999: 369) stretching across international borders, then looking for how social change happens in individual countries implies understanding what processes are going on within this continuum. Influences include both the direct transmission of new ideas, practices, etc., in both directions, and also more indirect influences. Thinking sociologically, processes such as socialisation, social mobility and social activism, studied by mainstream sociologists within the confines of nation-states, sometimes occur across international borders, especially when almost all sections of a society are liable to migrate, the population of co-nationals living in a foreign country is heterogeneous, and transnational fields are dense. Anthias (2012: 103) claims that 'all people... inhabit transnational spaces in the modern world' and inside the EU in particular this is surely nearly true.

Many scholars (for example, Castles et al 2014: 16) note the differentiated quality of migration today. This is especially marked in the EU, because of the diverse opportunity structures offered by EU citizenship. Migration diversity in turn promotes diversity of impacts. When people leave, they often do not 'emigrate' in the sense of settling abroad, but participate in various types of mobility. Workers engaging in occasional or regular temporary work abroad; pensioners spending winters in a sunnier country; students taking a sequence of scholarships and internships in different countries; family and friends visiting their contacts living abroad: all are typical of mobility in developed countries and especially within the EU. As shown for example in 
OECD (2013), 'return' to the country of origin is therefore also often provisional, and this affects the impact of 'returnees' on the sending society. Receiving countries also vary, therefore migration-related influences from one will be different from the next. For example, Carletto and Kilic (2011) show that the social mobility of returnees to Albania is lower from Greece than from Italy.

As Levitt (2001: 67-8) observes, the extent of difference between sending and receiving countries also affects influence. The poor-sending to rich-receiving country stereotype often fails to describe reality, for instance regarding mobility between equally or nearly equally wealthy European countries, a parity which might result in particularly intense cultural exchange. Finally, it is also important to see that all sending-receiving country pairings share points of similarity as well as difference: the existence of similarities as well as differences may be important in helping determine how the interlocking of the two societies creates migration effects.

Kapur (2010: 14), writing about the political economy of diaspora engagement with India, identifies four channels of migration impact: an absence channel, a prospect channel (where stayers' behaviour is shaped by the prospect of future migration), a diaspora channel and a return channel. The absence channel is similar to the 'gaps' approach discussed above. The other channels represent three aspects of transnationalism. This tripartite framework, adapted from Kapur, is useful, with modifications, for understanding migration impact in the EU.

With regard to the prospect channel, an important impact is the emergence of migration cultures in locations with dynamic migration networks, where many people expect to migrate, for example in Romania (Horváth 2008) or Poland (White 2016). As for the diaspora channel, the concept of a diaspora in the sense of a population of migrants feeling collective responsibility towards the homeland is problematic in the 
case of CEE countries (see below). However, if the salient feature of a diaspora is that it is a scattered population (and migrants from CEE are to be found across Western Europe, as well as further afield), using the word 'diaspora' can aid understanding the geographical complexity of transnational ties. Kapur's final, 'return channel' is important in Europe, if it is understood to include temporary return. Returnees can be particularly influential when they continue to live within strong transnational fields (labelled by Anghel et al 2019 'transnational return'). Their influence may be especially strong when, as in Poland, they tend to return to the same locations which they left. Stayers who return from visiting friends and family abroad should also be taken more into account in scholarly literature.

Migration impacts can be separated into indirect and direct. Indirect influences include, for example, changing power relationships and social stratification, identified by Portes (2010) as changes to the social structure. Although some analysts (notably Boccagni and Decimo 2013) appear to class all types of social impact as social remittances, in our book we keep the indirect impacts analytically separate from social remittances and reserve 'social remittances' for instances of conscious adoption and direct transmission of foreign ideas, attitudes, practices, etc. (The list is slightly different even within individual works by Peggy Levitt, who coined the phrase.) As mentioned in the introduction, understanding how social remitting takes place is essential for applying the inside-out approach, hence the importance of applying recent scholarship about the phenomenon. A few of the many relevant points about social remittances are discussed below. (For extended discussion of social remittances see, for example, Boccagni and Decimo 2013; Levitt 2001; Nowicka and Šerbedžija 2016.)

Understanding the mechanism of remitting is particularly important for applying the inside-out approach. As suggested by Grabowska, Garapich and their colleagues 
(Grabowska and Garapich 2016, Grabowska et al 2017), the social remitting process can be analysed in stages, from acquisition through transmission to diffusion. The first stage is the most researched part of the process, particularly since many researchers who are not interested in sending countries and do not use the term 'social remittances' investigate the same phenomenon under the heading of 'integration'. The environments, circumstances and character traits of individual migrants can be more or less favourable for social remitting. Grabowska (2016) and Blum (2015) argue that remitters are distinguished by their capacity for reflexivity. Importantly, one should not just assume that it is more educated people who are more open to new ideas.

A number of scholars also note that social remitting rarely involves uncritical adoption of all things foreign. Migrants and their visitors from sending countries are more discriminating. Arcimowicz et al (2015: 381) for example conclude from a large qualitative study of stayers in Poland, which captured their impressions from visits and stays abroad, that they did not divide neatly between cosmopolitans and traditionalists. Each interviewee liked some foreign practices (such as good organisation and friendliness to strangers) but rejected others (for example commercialised holidays such as Valentine's Day). Blum (2015) shows that in Kazakhstan young people returning from the USA rarely try to implement taboo practices such as sitting on the ground; occasionally become involved in volunteering, although finding little sympathy for this among locals; but do successfully persuade (female) contacts of the merits of greater gender equality, as observed in the USA.

The diffusion stage of social remitting is the most under-researched. As a number of researchers have noticed, individual social remitting often happens on-line. Trandafoiu (2013) shows how Romanian stayers and migrants mutually shape their ideas in on-line discussion forums. This compares with studies of transnational Polish 
internet forums by Galasińska (2010) and Siara (2009), although it is a shame that none of the authors attempts to chart diffusion through the wider networks of participants. Grabowska et al (2017) interviewed fans of individual return migrants, who testified to how these returnees' ideas were catching on locally. Political remittances research to some extent captures diffusion, especially research into the 'transnational action space' showing how inspirational ideas, for example about how to organise LGBT activism (Binnie and Klesse 2013), can be spread through LGBT organisations and/or social media.

However, much remains mysterious about how - if at all - individual changes of behaviour add up to change throughout society. Levitt and Lamba-Nieves (2011: 3) ask how social remittances 'scale up' to 'influence regional and national changes'. Diaspora researchers to some extent are interested in how diasporas diffuse ideas 'downwards' to sending country stayers. However, tracing how individual social remittances are passed on from stayer to stayer is often impossible, in view of the multitude of other influences. Rather than seeing influence as spreading 'up' or 'down', we adopted a third approach and investigated exactly how migration (including both indirect effects and social remittances) sat side-by-side with other determinants of change or continuity. In other words, it is the nature of this horizontal relationship which seemed most important to research in order to understand how regronal and national change results from migration.

According to de Haas (2012: 19) 'migration tends to reinforce (pre-)existing trends.' Levitt and Lamba-Nieves (2011: 3) argue that social remittances 'are distinct from, but often reinforce and are reinforced by, other forms of global cultural circulation'. Blum, Levitt and Lamba-Nieves and de Haas illustrate how migration contributes to changes in societies (Kazakh, Dominican and Moroccan) which are 
already changing for other reasons. However, these are not sociological studies of the countries, but studies of migrants. For example, although Blum's book contains plenty of first-hand impressions of how Kazakh society is becoming less traditional, he does not provide evidence of this from secondary sources. My alternative approach is to survey published data about the sending country society first, only afterwards embedding migration in this mainstream sociology, as Castles (2010) recommends. The following section discusses my attempt to do this in the case of Poland.

\section{Poland - Steps in Applying an Inside-Out Approach}

The scale of mobility, and density of transnational ties, made Poland a suitable case study for the impact of migration (and more specifically EU mobility) on a single sending ${ }^{4}$ country. In December 2017, for example, 2.2 million Poles with permanent residence in Poland had been living in other EU countries for more than three months (GUS 2018a). Moreover, Poland is full of return migrants. In 2016, 12 per cent of Poles resident in Poland had worked abroad in the last ten years, including 27 per cent of 2534-year-olds (Cybulska 2016: 1). Transnational ties in individual households are often three-way, or even more complex, leading to numerous reference points and channels of influence.

Mobility affects the whole of Poland. Post-2004 Polish migrants come from all regions (GUS 2018b: 461), although labour migration from cities with over 500,000 inhabitants was marked only around 2004, when EU accession coincided with peak unemployment rates, including graduate unemployment, as well as a wave of enthusiasm for taking advance of mobility rights to explore the West. Many young people left Polish cities, often apparently for good (Okólski and Salt 2014). My

\footnotetext{
${ }^{4}$ Although statistics are uncertain, Poland today experiences net immigration, thanks to a recent influx of Ukrainians, most of whom are temporary migrants.
} 
interview evidence (see below) shows they left a wake of transnational ties. Nowadays, when places such as Warsaw and Wrocław are wealthy even by EU standards, questions about migration's impact on the city can raise eyebrows and provoke the rejoinder that migration is mainly from smaller cities, towns and villages. On reflection, however, even individuals who have never lived abroad themselves do usually admit to having personal acquaintances among migrants, especially if study at foreign universities and short working visits abroad are defined as migration.

The methodology used in my own chapters for White et al (2018) followed a sequence of steps.

1. Identifying important areas of change in CEE.

2. Mapping social trends in Poland, particularly since 2004.

3. Examining existing qualitative (non-migration) sociological and anthropological studies for evidence of migration influence.

4. Reviewing the findings of migration scholarship (including my own previous research) about migration impacts, especially how migrants interact with stayers.

5. Designing and executing additional fieldwork to identify impact in cities.

6. Conceptualising how migration-driven and other types of change fit together.

The important trends in CEE countries might seem easy to identify (compared for example to West European countries) thanks to the region's recent history of transitioning away from communist regimes and towards democracy and EU accession. After a rocky start in the 1990s, there is evidence that, for example, in recent years civil society has been strengthening, opportunities for women have increased and income inequalities have reduced in many countries across the region (Jacobsson 2015, HDR, ${ }^{5}$

${ }^{5}$ http://hdr.undp.org/en/data Human Development Data (1990-2017): Gender. Last accessed 31 December 2018. 
Eurostat). ${ }^{6}$ Accepting that this overall trajectory exists does not imply subscribing to the view that CEE was 'catching up' with the West - which had its own problems and could not always be a model - or asserting that there has been 'progress' everywhere. For example, minority rights, although better protected in theory, have been patchily observed (Rechel 2009). Since the 1990s, anthropologists have been debunking facile assumptions about unilinear change, pointing to narratives of resistance to neoliberalism; persisting low levels of trust in politicians and the state; and reluctance to believe that positive change is more than propaganda. The rise to power of populist governments in countries like Poland and Hungary indicates that previous governments were viewed as being insufficiently concerned with society's needs - although this does not equate to the claim (frequently made) that, overall, conservative values are crowding others out. Many Polish voters, for example, were happy to vote in 2015 for higher child benefits and against corruption, but opinion polls show that only a minority support a total ban on abortion.

The next step was to look specifically at important Polish trends, on which there is an abundance of publicly available statistical information, although all survey evidence naturally needs to be approached critically and should not be assumed to present a perfect depiction of 'reality'. Just browsing through statistics was also rewarding; one serendipitous find regarding gender equality, for example, was the information that the percentage of women holding driving licences had increased since EU accession, from 30 per cent in 2007 to 48 per cent in 2015 (Czapiński and Panek 2007: 42; Czapiński and Panek 2015: 34) This matched with the findings of sociologists about the increase in women driving in a probably typical small town where many

${ }^{6}$ http://ec.europa.eu/eurostat/tgm/refreshTableAction.do?tab=table \&plugin=1\&pcode=t $2020 \_50 \&$ language $=$ en People at risk of poverty or social exclusion.

Last accessed 9 January 2019. 
husbands worked abroad (Kurczewski and Fuszara 2012: 92-3): one of many causes for the increase in women drivers.

Trends in Poland since 2004 included, for instance, an increase in various types of individualisation, such as a more personalised approach to religion. In 2005, 66 per cent of respondents in a national survey had stated that 'I am a believer and I adhere to the Church's teachings', while 32 per cent said, 'I am a believer in my own way'. By 2014, only 39 per cent claimed to adhere to the Church's teachings and 52 per cent 'believed in their own way' (Boguszewski 2015: 40). Society is becoming more open in some respects. For example, tolerance of LGBT people has been increasing significantly, despite rising levels of reported hate crime and an active anti-LGBT movement (Gołębiowska 2014, Głowacki 2017). Tolerance of refugees has dropped since 2015 but friendly feelings towards most nationalities have risen since $2004{ }^{7}$ As Slany shows in White et al (2018), although full gender equality is a distant prospect, there is more acceptance for equal gender roles and some evidence that men are playing a greater role in childcare.

In the Polish case, the isolation of migration studies from mainstream sociology decried by Castles is not complete, but the gap is significant, particularly at national level. Despite the wealth of statistical data broken down by age, place of residence, political affiliation, etc., hardly any surveys take into account whether respondents possess migration experience. I also explored a great deal of qualitative sociological research, but found that only a few local-level studies tried to factor in migration, as in the example of women drivers mentioned above. In another example, Kubicki (2015: 103) mentions villagers from south-east Poland bringing back more tolerant attitudes to

\footnotetext{
${ }^{7}$ These assertions are based mostly on various CBOS reports. For more detailed analysis, see White et al 2018, Chapter 8.
} 
diversity as a result of living abroad. Disappointingly, however, linking migration and specific social trends was something I largely had to undertake myself.

Step four involved establishing what Polish migration scholarship revealed about indirect migration influences (which because of space constraints I do not discuss in detail in this article) as well as social remitting. Fortunately, new research by migration scholars into Polish social remitting provided plenty of evidence about what types of remitting were taking place, even if the authors rarely mention the details of specific Polish social trends. Recent studies include Dzięglewski 2016, Gawlewicz 2015, Grabowska et al 2017, Haynes and Galasińska 2016, Karolak 2016 and Nowicka 2018. Cieślik 2011, Rzepnikowska 2017 and Siara 2009, though not using the social remittances concept, cover similar ground.

This research (together with my own previous studies) made it easier to conceptualise in advance how and where migration influences might be occurring, or not: indicating, for example, the importance of workplaces and families as domains of social remitting, and showing the types of difference which Poles found particularly striking abroad, such as ethnic diversity and less hierarchical workplaces. To some extent it was also possible to use existing studies to chart social trends within Polish society abroad, such as falling involvement in organised Catholicism. Fortunately, too, there have been a number of studies of return migration, though not enough: most studies date from around 2008-12. However, these do provide invaluable information about, for example, the facts that at least half of returnees may be considering further trips abroad, and that people tend to return to their home towns. As argued above, this potentially makes them more influential as agents of change, although, as Garapich (2016a) shows, they sometimes feel inhibited by their image of home towns as places 
that will never change. Many studies show that returnees consider themselves to bring soft skills back from abroad, especially language skills.

The fifth step was to design a study to understand migration impact in cities. My chapters in White et al (2018) built partly on my previous Polish migration projects ${ }^{8}$ based on interviews and observation in small towns, where the influence of migration was visible in new housing, reduced unemployment, etc.: the textbook impacts of migration. (I had however also gathered plenty of evidence about ideas travelling between migrants and stayers.) By contrast, the impact of migration on cities remained an enigma. Polish statistical data ${ }^{9}$ consistently shows that the largest cities enjoy higher standards of living and contain a greater share of highly educated and more liberal residents than most other places in Poland. Beginning with Wrocław, whose tag is 'Wrocław the Meeting Place' and whose officials exhibit emigration denial (White 2016), in 2015-6 I interviewed 49 people of different ages and social backgrounds, ${ }^{10}$ including 22 return migrants, in four Polish cities. Despite the urban locations, interviewees, just like small-town residents, lived to some extent within transnational social space and had plenty to say about ideas and practices exchanged within transnational families; comparisons between workplace experiences in Poland and

${ }^{8}$ For my 2006-13 projects on return migration and family migration from Polish small towns and villages I interviewed a total of 229 people, most of them in Poland.

${ }^{9}$ For example, as gathered by the main polling organisation CBOS and the government statistical agency GUS.

${ }^{10}$ As in most of my previous projects, I offered payment for all the 2016 interviews, which helped secure the participation of less well-educated and poorer interviewees who might otherwise not have come forward. 
abroad; changing tastes in food; and many other matters. Unlike small-town residents, they often had day-to-day encounters with foreigners in Poland, and this facilitated discussions about ethnic diversity. Hence it was feasible to build on previous studies of Polish social remitting to shape the interview topic guide, and there was plenty of information about migration impact to be garnered.

Referring back to Levitt's (2001: 67-8) point that the degree of similarity between the sending and receiving countries is an important variable: although the similarities between lifestyles in Western and Polish cities might be supposed to diminish the range of influences, the opposite proved true. In line with contact theory, the sense of equality with Western foreigners, particularly when these were members of one's extended, bi-national family, promoted exchange of ideas and practices. For example, in Wrocław 'Wanda' described a deliberate mutual 'intertwining' of Polish and British culture with a daughter settled in the UK. In addition to detailing what impressed her in England, such as the fact that her daughter was married by a woman priest, she explained how she and her husband tried to bring ideas - such as about practical Christmas presents - on visits to their British in-laws. Moreover, even if Wanda had acquired new religious preferences which could not (yet) lead to institutional change in Poland, thanks to living in a Polish city, she was, like her fellow interviewees, more able than other Poles to put into practice leisure and eating practices picked up abroad. This was partly because of shops and services but also because they did not seem to face the same type of resistance to change encountered by some wouldbe social remitters in small towns (Garapich 2016a).

The final stage was to conceptualise how migration-driven and other types of change fitted together. As mentioned, the book (except Kaczmarczyk's chapter on the economy) did not set out to establish what proportion of change was due to migration. It 
focused on how migration reinforces or holds back change. Migration, for example, helps add to the number of Poles who are confident in foreign languages and to the number of women driving cars, an aspect of gender equality. It accelerates those particular trends, which are also occurring for other reasons. The book also provides examples of how more open-to-difference attitudes were being transmitted, contributing to a trend which seemed clear in survey evidence from 2004 to 2015 but whose continuation has often been questioned since 2015, in face of intolerant pronouncements by certain Polish politicians and a groundswell of opposition to refugees.

In some cases it is possible to identify both social remittances and indirect migration effects working in the same direction, as in the case of the trend towards more gender equality in Poland, where indirect effects such as the redistribution of household labour (or driving responsibilities) in migrant families are probably more important than direct persuasion.

However, in gender equality or attitudes to diversity, as in a number of other areas, there exist both trends and counter trends, as O'Dwyer (2018) has shown for example in the case of how the (transnational) Polish LGBT movement has been strengthened thanks to an anti-LGBT backlash. Studying migration influences puts the causes of particular trends under the microscope and exposes the competing directions of change. Another example concerns the rather small growth in generalised trust, the propensity to trust people who are not personal acquaintances. In line with theories linking prosperity to trust, the growth in both incomes and income equality in Poland since 2004 (Sztabiński and Sztabiński 2014) might have been expected to lead to a greater increase in trust than actually occurred. Social remittances could have added to the positive trend, since qualitative data consistently shows that Poles abroad are impressed by manifestations of generalised trust and civility in foreign countries. On the 
other hand, migration influences help explain why levels of generalised trust remain low. Many researchers have illustrated mistrust among working-class Poles abroad, fed by a 'discourse of hostility', expectations that 'Poles behave like wolves to fellow Poles' and what Garapich (2016b: 241-51) labels the 'myth of the Polish conman'. These myths and discourses also infect Polish stayers. For example, Grzegorz, a 21-year Warsaw student with relatives in London, told me in 2016 that 'lots of people complain it's best for Poles abroad to avoid other Poles. In fact, you can see it in Poland too. A Pole always wants to do down other Poles' (White et al 2018: 149-50).

Another way of understanding more precisely how migration reinforces or undermines social change is to distinguish between supply and demand. This helps us see how certain migration influences back up other supply-side or demand-side factors. For example, the number of adult Poles studying English has sharply increased; this is partly because migrants need to know languages, but also because stayers in Poland with relatives abroad (like Wanda) are learning English.

The book's most important contribution to understanding how migration influences sit side by side with other determinants of change is the idea that migration has more 'value-added' for some social groups and in some geographical areas. This follows on from research by other scholars into cosmopolitanism and European identities, pointing out that working-class people can be become more open to difference as a result of migration (Datta 2009) and even that the 'impact of transnational practices on European identity is stronger among the low educated than among the highly educated' (Kuhn 2012: 995). Middle-class milieux, especially in Polish cities, are already changing for a multitude of reasons. As already mentioned, survey evidence tends to show that residents in the bigger cities hold increasingly liberal views. Migration can speed up these trends, when, for example, urban students 
participate in educational exchanges abroad. However, on a smaller scale, increasingly open attitudes can also be observed in smaller places and among less-educated parts of the population.

For example, the sociologist Feliksiak (2013: 61) notes a growth in tolerance of homosexuality in Polish small towns and also in the number of small-town residents knowing openly gay people; he finds this difficult to explain, and suggests it might be easier to come out in small towns, but it is more likely to occur because small town residents have lived abroad. This levelling effect (where liberal attitudes spread even in less favourable environments) is illustrated by my own and other scholars' examples of less-well educated and small-town/rural interviewees, who are not so likely to pick up positive attitudes towards ethnic diversity or LGBT people in Poland, but sometimes do so abroad. Within Poland, it is harder to diffuse liberal ideas outside the biggest cities, but the acquisition of social remittances is in itself significant: for example, if the share in the population of Poles who accept homosexuality as normal continues to rise, this in itself is a facet of social change.

\section{Applying the Approach to other Countries in CEE}

Most countries in CEE score highly on the Human Development Index and do not fit easily into traditional, development-based frameworks for analysing the impact of migration on sending countries. As in the Polish case, it seems more helpful to look for migration influences in CEE in the context of individual social remitting, rather than actions of diaspora organisations. Westward migration from CEE is a migration of individuals and their friends and families, who are dispersed to many locations abroad. Moldova has a few examples of home-town associations (Cingolani and Vietti 2018), 
but I am not aware of any others; Moreh (2014: 1764) concurs, with regard to Romanians in Spain, that there are no hometown associations.

To some extent, it is possible to map social trends in CEE from international surveys, including the European Social Survey, European Values Survey and Eurobarometer. Digging into locally-produced data often requires knowledge of the local language. As for qualitative studies: scholars from CEE are increasingly wellrepresented in English-language journals, although publications in English represent only the tip of the iceberg of CEE sociological research. For example, the Vytautas Magnus University Emigration Institute has published a migration journal, OIKOS, since 2006, but most articles are in Lithuanian. ${ }^{11}$ Migration research in English is most plentiful about Poland and Romania (see for example Anghel et al (2017) on the Romanian literature).

CEE societies differed considerably in the communist period, and diversity is even more marked today, despite the common denominator for many of EU membership. Moreover, the scale and nature of migration varies considerably. Countries in former USSR and south-east Europe generally receive more economic remittances, which range from 20.5 per cent of GDP in Moldova to 1.3 per cent in Poland and 1 per cent in Slovenia (less than Portugal). ${ }^{12}$ Migration's different geographical impact also links to regional inequality, which is pronounced in CEE. Kahanec and Kureková (2016: 194) for example illustrate diverse volumes of migration from different Slovak regions in 2004-11: patterns linked to 'regional labour market conditions'.

\footnotetext{
${ }^{11}$ http://www.iseivijosinstitutas.lt/contents. Last accessed 13 January 2019.

${ }^{12}$ https://www.knomad.org/data/remittances. Remittance inflows (December 2018). Last accessed 9 January 2019.
} 
Nonetheless, there are common trends, as mentioned earlier in this article, and existing qualitative research points to some similar types of migration influence, including social remittances. The perpetuation of informal practices and relations characteristic of the communist period - is manifest in extensive use of informal migration networks. At the same time, there seem to be social remittances with regard to a changing legal culture, where individuals become more inclined to respect official rules, as Kubal $(2012,2015)$ illustrates for both Poland and Ukraine. Nedelcu (2012) writes about the spread of open-to-difference attitudes among Romanians who visit their relatives in Toronto. In general, migration promotes more self-confidence, which links to more individualism and sense of personal autonomy.

Several studies show how women from the region are favourably impressed by greater equality for women which they see abroad (for example Vullnetari (2012) on Albanians) and how this sometimes translates into attempts to make changes in the origin country (such as Vlase (2013)'s evidence of how some Romanian women encourage their adult daughters to be more ambitious). With regard to other kinds of equality: Anghel (2016) has studied how Roma returnees raise their economic status locally in Romania thanks to migration; Grill (2012) has similar findings on Slovakia. With regard to democratisation: Levitz and Pop-Eleches (2010: 476) suggest that 'the high importance of migration in Bulgaria and Romania... seems to facilitate social learning and contributes to greater domestic pressures for better democratic governance' (cf. more mixed conclusions regarding Poland in Ahmadov and Sasse 2016). On the other hand, as remarked above, discontent with the achievements of liberal governments in CEE and support for populist parties links to perceptions that living standards for ordinary people should have risen more than they have done. This discontent surely links directly to unfavourable comparisons made with Western countries. 
Another cross-CEE international migration impact worth investigating is the rather low rate of internal migration. Ease of mobility within the EU is one factor depressing internal migration (Bélorgey et al. 2012). It re-shapes perceptions of near and far, where West European countries seem near and cities within one's country of birth are regarded as far and unattractive. As Hazans (2016: 314) writes about Latvia, Lithuania and Estonia, when everyone now has close family members and friends abroad, international migration becomes the 'new normal'.

As these examples suggest, there is a base of broadly comparable qualitative research about CEE. It would be possible to write about the impact of migration on Lithuania or Romania applying an approach similar to our Polish study. The approach could indeed be applied to any country from which people migrate, even those not generally regarded as possessing 'sending' identities. Twenty-first century Europe, particularly the EU, with intense and diverse migration between quite similar neighbouring countries, is a rewarding laboratory for studying sociological phenomena transnationally. Within Europe, post-communist countries are particularly interesting objects of study, given the dynamism of social change since the collapse of communism. However, many trends discussed in this article occur in Western Europe as well.

\section{Conclusion}

De Haas (2012: 19) and Levitt and Lamba-Nieves (2011: 3) argue that migration reinforces other social trends and thereby contributes to social change. However, scholars agree on the difficulty of disentangling migration-related from other influences. This article has recommended using a mixed methods approach, first to map social 
trends inside a given country and then to analyse the changing lives of individuals within the transnational social space. This includes studying social remitting: interactions between stayers and migrants which can lead to changes in behaviour and attitudes. The approach thus combines quantitative and qualitative 'mainstream' sociology with migration studies to conceptualise how reinforcement actually occurs.

Disaggregating national trends, it appears that change happens more slowly among some social groups than others, but it does happen. It is that slower change which may be more attributable to migration than, for example, to education. At least in Poland, migration-related change seems to be more significant in changing the lives of less well-educated and/or poorer and/or older people, and/or those living outside the main cities, not just economically, but also culturally. The new housing and cars with foreign licence plates in small towns are easy to see, but return migrants as well as stayers who visit relatives living in foreign countries also gain new language skills and reflections about patterns of behaviour observed abroad. It may be harder for cultural change to happen in such locations, but, when it does happen (as in the example of decreasing hostility towards homosexuality in small towns), it is more likely to happen because of migration. On the other hand, change in the form of diffusing new ideas and/or adopting new lifestyles is more easily implemented among educated, wealthy big-city dwellers, whose lives are already changing more quickly for a host of reasons.

As Portes (2010) observed, migration-related factors can also reinforce conservatism, and, where data about trends shows that change is happening only slowly, it can be useful to seek out the competing forces which are both promoting change and holding it back. So, for example, one might suppose that generalised trust in Poland should be rising faster (given rising prosperity, education, respect for the law, etc.) but 
widespread myths about the untrustworthiness of Poles abroad help undermine this trend.

Applying the inside-out approach thoroughly would require more collaboration between mainstream sociologists of sending countries and migration scholars. Data about the migration experience of survey respondents could helpfully be included in social surveys on every topic, alongside age, sex and other socio-demographic characteristics. Qualitative sociologists could also be more alert to the fact that their research subjects live in transnational social fields and, when they investigate specific areas of social change, keep an eye open for influences coming from abroad.

The article argued that the Polish case study is applicable to other countries in CEE. However, as the discussion of the UK and Germany suggested, the Polish case offers pointers towards understanding the impact of migration on sending countries even in Western Europe, where mobility is also intense, migration is largely an individual or family project, and many stayers keep in touch with individual people abroad. In other geographical contexts, collective remittances may be more important, and migration impact more deliberate and institutionalised because of links to development policies. Nonetheless, applying an inside-out approach facilitates a broad understanding of trends within each sending country, not all of which may have obvious links to 'development', and prompts reflection on how these link to migration.

\section{References}

Ahmadov A. and G. Sasse. 2016. 'Empowering to engage with the homeland: do migration experience and environment foster political remittances?' Comparative Migration Studies 4, no. 12: 1-25. 
Arcimowicz J., M. Bieńko and B. Łaciak. 2015. Obyczajowość. Polska początku XXI wieku - przemiany, nowe trendy, zróżnicowania. Warsaw: Żak.

Anghel, R. 2016. 'Migration in differentiated localities: changing statuses and ethnic relations in a multi-ethnic locality in Transylvania, Romania.' Population, Space and Place 22, no. 4: 356-66.

Anghel, R., A. Botezat, A. Coşciug, I. Manafi and M. Roman. 2017. International Migration, Return Migration, and their Effects. A Comprehensive Review of the Romanian Case. CELSI Discussion Paper 43. Bratislava: CELSI.

Anghel R., M. Fauser and P. Boccagni (eds.). 2019. Transnational Return and Social Change: Social Hierarchies, Ideas, and Social Identities. London: Anthem Press.

Anthias, F. 2012. 'Transnational mobilities, migration research and intersectionality.' Nordic Journal of Migration Research 2, no. 2: 102-110.

Bélorgey N., B. Garbe-Emden, S. Horstmann, A. Kuhn, P. Stubbs and D. Vogel. 2012. Social Impact of Emigration and Rural-Urban Migration in Central and Eastern Europe. Brussels: European Commission.

Benton, M. 2017. Safe or Sorry? Prospects for Britons in the European Union after Brexit. Washington DC: Migration Policy Institute Europe.

Binnie, J. and C. Klesse. 2013. "'Like a bomb in the gasoline station”: East-West migration and transnational activism around lesbian, gay, bisexual, transgender and queer politics in Poland.' Journal of Ethnic and Migration Studies 39, no.7: $1107-24$.

Blum, D. 2015. The Social Process of Globalization: Return Migration and Cultural Change in Kazakhstan. Cambridge: Cambridge University Press.

Boccagni, P. and F. Decimo. 2013. 'Mapping social remittances.' Migration Letters 10, no. 1: 1-10.

Boguszewski, R. 2015. 'Zmiany podstawowych wskaźników religijności Polaków po śmierci Jan Pawła II'. In M. Grabowska (ed.) Religijność i Kościół 10 lat po śmierci Jana Pawła II. Warsaw: CBOS, 35-48.

BMA (British Medical Association). 2015. 'NHS brain drain: why the busman's holidays?' https://www.bma.org.uk/news/2015/august/nhs-brain-drain-why-thebusmans-holidays, last accessed 9 January 2019.

Cable, S. 2014. 'Out of sight, out of mind! Half of Britons have friends and family living abroad... but two-thirds don't bother keeping in touch. Daily Mail. 4 
November. https://www.dailymail.co.uk/travel/travel_news/article-

2818748/Out-sight-mind-Half-Britons-friends-family-living-abroad-two-thirdsdon-t-bother-keeping-touch.html, last accessed 9 January 2019.

Carletto, C. and T. Kilic. 2011. 'Moving up the ladder? The impact of migration experience on occupational mobility in Albania.' The Journal of Development Studies 47, no. 6: 846-869.

Castles, S. 2010. 'Understanding global migration: a social transformation perspective.' Journal of Ethnic and Migration Studies 36, no. 10: 1565-86.

Castles, S., H. de Haas and M. Miller. 2014. The Age of Migration: International Population Movements in the Modern World. 5th ed. Basingstoke: Palgrave Macmillan.

Cieślik, A. 2011. 'Where do you prefer to work? How the work environment influences return migration decisions from the United Kingdom to Poland.' Journal of Ethnic and Migration Studies 37, no. 9: 1367-83.

Cingolani, P. and Vietto, F. 2018 'My children think differently.' Transnationalism, social remittances, and intergenerational differences among Moldovan migrants in Italy, paper delivered at the 2018 IMISCOE annual conference, Barcelona, 24 July.

Cybulska, A. 2016. 'Praca za granicą.' Research Report. Warsaw: CBOS.

Czapiński, J. and T. Panek (eds.) 2007. Diagnoza Społeczna 2007: Warunki i Jakość Życia Polaków; Raport. Warsaw: Rada Monitoringu Społecznego.

Czapiński, J. and T. Panek (eds.) 2015. Diagnoza Społeczna 2015: Warunki i Jakość Życia Polaków; Raport. Warsaw: Rada Monitoringu Społecznego.

Dahinden, J. (2016) 'A plea for the "de-migranticization' of research on migration and integration", Ethnic and Racial Studies, 39, no. 13: 2207-25.

Datta, A. 2009. 'Places of everyday cosmopolitanisms: East European construction workers in London'. Environment and Planning A 41, no. 2: 353-70.

De Haas, H. 2012. 'The migration and development pendulum: a critical view on research and policy.' International Migration 50, no. 3: 8-25.

Dzięglewski, M. 2016. 'Return migration and social change in Poland: "closures" to migrants' non-economic transfers.' Central and Eastern European Migration Review 5, no. 2: 167-88. 
Faist, T. 2016. 'Cross-border migration and social inequalities.' Annual Review of Sociology 42: 323-46.

Feliksiak, M. 2013. ‘Stosunek do praw gejów i lesbijek oraz związków partnerskich.’ In M. Grabowska (ed.) Rodzina i jej przemiany.Warsaw: CBOS, 60-71.

Galasińska, A. 2010. 'Leavers and stayers discuss returning home: internet discourses on migration in the context of the post-communist transformation.' Social Identities 16, no. 3: 309-24.

Garapich, M. 2016a. 'I don't want this town to change': resistance, bifocality and the infra-politics of social remittance.' Central and Eastern European Migration Review 5, no. 2: 155-66.

Garapich, M. 2016b. London's Polish Borders: Transnationalizing Class and Identity among Polish Migrants in London. Stuttgart: Ibidem.

Gawlewicz, A. 2015. "We inspire each other, subconsciously": the circulation of attitudes towards difference between Polish migrants in the UK and their significant others in the sending society.' Journal of Ethnic and Migration Studies 41, no. 13: 2215-34.

Glick Schiller, N. 2012. 'Unravelling the migration and development web: research and policy implications.' International Migration 50, no. 3: 92-97.

Głowacki, A. 2017. 'Patriotyzm, nacjonalizm i stosunek do obcych.' In Młodzież 2016, edited by M. Grabowska and M. Gwiazda. Warsaw: CBOS, 127-42.

Gołębiowska, E. 2014. The Many Faces of Tolerance: Attitudes towards Diversity in Poland. London: Routledge.

Grabowska I. 2016. Movers and Stayers: Social Mobility, Migration and Skills. Frankfurt Am Main: Peter Lang.

Grabowska, I. and M. Garapich. 2016. 'Social remittances and intra-EU mobility: nonfinancial transfers between U.K. and Poland.' Journal of Ethnic and Migration Studies 42, no. 13: 2146-62.

Grabowska, I., M. Garapich, E. Jaźwińska and A. Radziwinowiczówna. 2017. Migrants as Agents of Change: Social Remittances in an Enlarged European Union. Basingstoke: Palgrave Macmillan.

Grill, J. 2012. "“Going up to England”: exploring mobilities among Roma from Eastern Slovakia.' Journal of Ethnic and Migration Studies 38, no. 8: 1269-87. 
Guarnizo, L., A. Sanchez and E. Roach.1999. 'Mistrust, fragmented solidarity, and transnational migration: Colombians in New York City and Los Angeles.' Ethnic and Racial Studies 22, no. 2, 367-396.

GUS (Główny Urząd Statystyczny). 2018. Informacja o rozmiarach i kierunkach czasowej emigracji z Polski w latach 2004-2017: Notatka informacyjna. Warsaw: GUS.

GUS (Główny Urząd Statystyczny). 2018. Rocznik demograficzny 2018. Warsaw: GUS.

Hazans, M. 2016. 'Migration experience of the Baltic countries in the context of economic crisis.' In Labor Migration, EU Enlargement, and the Great Recession, edited by M. Kahanec and K. Zimmermann. Berlin: Springer, 297344.

Haynes, M. and A. Galasińska. 2016. 'Narrating migrant workplace experiences: social remittances to Poland as knowledge of British workplace cultures.' Central and Eastern European Migration Review 5, no. 2: 41-62.

Horváth, I. 2008. 'The culture of migration of rural Romanian youth.' Journal of Ethnic and Migration Studies 34, no. 5: 771-86.

Jacobsson, K. (ed.) 2015. Urban Grassroots Movements in Central and Eastern Europe. Farnham: Ashgate.

Kahanec, M. and L. Kureková. 2016. 'Did post-enlargement EU labor mobility help the EU to adjust during the Great Recession? The case of Slovakia.' In Labor Migration, EU Enlargement, and the Great Recession, edited by M. Kahanec and K. Zimmermann. Berlin: Springer, 189-218.

Kapur, D. 2010. Diaspora, Development and Democracy: The Domestic Impact of International Migration from India. Princeton, NJ: Princeton University Press.

Karolak, M. 2016. 'From potential to actual social remittances? Exploring how Polish return migrants cope with difficult employment conditions.' Central and Eastern European Migration Review 5, no. 2: 21-39.

King, R. and R. Skeldon. 2010. 'Mind the gap!' Integrating approaches to internal and international migration.' Journal of Ethnic and Migration Studies 36, no. 10: $1619-46$.

Kubal, A. 2012. Socio-Legal Integration: Polish Post-2004 Enlargement Migrants in the United Kingdom. Farnham: Ashgate. 
Kubal, A. 2015. 'Legal consciousness as a form of social remittance? Studying return migrants' everyday practices of legality in Ukraine.' Migration Studies 3, no. 1: $68-88$.

Kubicki, P. 2015. 'Tożsamość w czasach zmiany: Polska lokalna w procesie integracji europejskiej.' Politeja 12 (33): 83-109.

Kuhn, T. 2012. 'Why educational exchange programmes miss their mark: cross-border mobility, education and European identity.' Journal of Common Market Studies 50, no. 6: 994-1010.

Kurczewski, J., and M. Fuszara. 2012. 'Modernizacja czy kryzys? Przemiany rodzin czasowych migrantów.' Societas/Communitas 1:79-108.

Lacroix, T. 2014. 'Conceptualizing Transnational Engagements: A Structure and Agency Perspective on (Hometown) Transnationalism.' International Migration Review 48, no. 3: 643-79.

Levitt, P. 2001. The Transnational Villagers. Berkeley: University of California.

Levitt, P. and D. Lamba-Nieves. 2011. 'Social remittances revisited.' Journal of Ethnic and Migration Studies 37, no. 1: 1-22.

Levitz, P. and G. Pop-Eleches. 2010. 'Monitoring, money and migrants: countering post-accession backsliding in Bulgaria and Romania.' Europe-Asia Studies 62, no. 3: 461-79.

Mădroane, I. 2016 'The media construction of remittances and transnational social ties: migrant-non-migrant relationships in the Romanian press.' Identities 23, no. 2: $228-46$.

Markova, E. 2010. 'Optimising migration effects: a perspective from Bulgaria.' In Black, R., G. Engbersen, M. Okólski and C. Panţîru, A Continent Moving West? EU Enlargement and Labour Migration from Central and Eastern Europe. Amsterdam: Amsterdam University Press, 207-30.

Mau, S., J. Mewes and A. Zimmermann. 2008. 'Cosmopolitan attitudes through transnational social practices?' Global Networks 8, no. 1: 1-24.

Moreh, C. 2014. 'Prestige and status in the migration process: the case of social differentiation in a Romanian “community” in Spain.' Journal of Ethnic and Migration Studies 40, no. 11: 1758-78. 
Nedelcu, M. 2012. 'Migrants' new transnational habitus: rethinking migration through a cosmopolitan lens in the digital age.' Journal of Ethnic and Migration Studies 38, no. 9: 1339-56.

Nowicka, M. 2018. "“I don't mean to sound racist but...": transforming racism in transnational Europe.' Ethnic and Racial Studies 41, no. 5: 824-41.

Nowicka M. and V. Šerbedžija (eds) 2016. Migration and Social Remittances in a Global Europe. London: Palgrave Macmillan.

O'Dwyer, C. 2018. 'The benefits of backlash: EU accession and the organization of LGBT activism in postcommunist Poland and the Czech Republic.' East European Politics and Societies 32, no. 4: 892-923.

Okólski, M. and Salt, J. 2014. 'Polish emigration to the UK after 2004: Why did so many come?' Central and Eastern European Migration Review 3, no. 2: 11-38.

ONS (Office for National Statistics). 2018. Migration Statistics Quarterly Report: November 2018.

OECD (Organisation for Economic Co-operation and Development). 2013. Coping with Emigration in Baltic and East European Countries. Paris: OECD Publishing.

Piperno, F. 2012. 'The impact of female emigration on families and the welfare state in countries of origin: the case of Romania.' International Migration 50, no. 5 : 189-204.

Portes, A. 2010. 'Migration and social change: some conceptual reflections.' Journal of Ethnic and Migration Studies 36, no. 10: 1537-63.

Rechel, B. (ed.) 2009. Minority Rights in Central and Eastern Europe. London: Routledge.

Rzepnikowska, A. 2017. 'Conviviality in the workplace: the case of Polish migrant women in Manchester and Barcelona.' Central and Eastern European Migration Review 6, no. 2: 51-68.

Siara, B. 2009. 'UK Poles and the negotiation of gender and ethnicity in cyberspace.' In: K. Burrell (ed.) Polish Migration to the UK in the 'New' European Union: After 2004. Farnham: Ashgate, 167-87.

Stockdale, A. and T. Haartsen. 2018. 'Editorial introduction: Putting rural stayers in the spotlight.' Population, Space and Place 24, no. 2: 1-8.

Sztabiński, P., and F. Sztabiński, (eds.) 2014. Polska: Europa - Wyniki Europejskiego Sondażu Społecznego, 2002-2012. Warsaw: IFiS PAN. 
Trandafoiu R. 2013. Diaspora Online: Identity Politics and Romanian Migrants. Oxford: Berghahn.

Vlase, I. 2013. 'Women's social remittances and their implications at household level: a case study of Romanian migration to Italy.' Migration Letters 10, no. 1: 81-90.

Vullnetari, J. 2012. 'Women and migration in Albania: A view from the village.' International Migration 50, no. 5: 169-88.

Wasek, A. 2007. 'Siemiatyckie Eldorado?' Nasz Dziennik, 9 February.

White, A. 2016. 'Social remittances and migration (sub)-cultures in contemporary Poland.' Central and Eastern European Migration Review 5, no. 2: 63-80.

White, A. 2017. Polish Families and Migration Since EU Accession. $2^{\text {nd }}$ ed. Bristol: Policy Press.

White, A. Grabowska, I., Kaczmarczyk, P. and Slany, K. 2018. The Impact of Migration on Poland: EU Mobility and Social Change. London: UCL Press. 